\title{
Dynamics of picocyanobacteria in the Seto Inland Sea (Japan) during summer
}

\author{
Yasuo Nakamura ${ }^{1}$, Shinobu Sasaki ${ }^{2}$, Juro Hiromi ${ }^{2}$, Kimio Fukami ${ }^{3}$ \\ ${ }^{1}$ Coastal Environment Research Team, National Institute for Environmental Studies, Tsukuba, Ibaraki 305, Japan \\ ${ }^{2}$ College of Agriculture and Veterinary Medicine, Nihon University, Setagaya, Tokyo 154, Japan \\ ${ }^{3}$ Faculty of Agriculture, Kochi University, Nankoku, Kochi 783, Japan
}

\begin{abstract}
Temporal and vertical changes of picocyanobacteria (PC) were monitored daily together with environmental variables during the summer stratification period (16 July to 9 August 1992) in the Seto Inland Sea, Japan. Coupled with wind mixing, $\mathrm{N}$ - and P-nutrients were introduced to the surface layer twice (19 July and after 30 July). A PC bloom $\left(5 \times 10^{4} \mathrm{ml}^{-1}\right)$ occurred following the first mixing event, and a rapid decrease of this bloom seemed to be attributed to high abundance $\left(>2 \times 10^{3} \mathrm{ml}^{-1}\right)$ of heterotrophic nanoflagellates (HNAN). In contrast, the second mixing event did not induce a PC bloom in spite of the high nutrient concentration, low abundance of HNAN $\left(<2 \times 10^{3} \mathrm{ml}^{-1}\right)$ and optimum temperature for growth. Field experiments on PC growth in the $<2 \mu \mathrm{m}$ seawater fraction conducted during the second mixing period revealed that addition of metal buffer solution enhanced the PC growth rates significantly. Although trace metal concentrations were not monitored and clean techniques were not used in the experiments, we infer that growth stimulation was not an experimental artifact, but due to Fe-deficiency of the PC populations. This is based on results obtained in our previous studies concerning trace metal contamination. It is suggested that Fe-deficiency was responsible for the lack of a PC bloom during the second mixing period.
\end{abstract}

\section{INTRODUCTION}

The ubiquitous and abundant distribution of picocyanobacteria $(\mathrm{PC})$ in the size range of 0.2 to $2 \mu \mathrm{m}$ (Sieburth et al. 1978) is now well documented, and the ecological importance of PC as primary producers has been highlighted in open ocean ecosystems (Johnson \& Sieburth 1979, Waterbury et al. 1979, reviewed by Waterbury et al. 1986 and Stockner 1988). Recent research has also revealed that in situ growth rates of $\mathrm{PC}$ are high $\left(>1 \mathrm{~d}^{-1}\right)$ and at the same time, PC are grazed vigorously by heterotrophic nanoflagellates (HNAN) and ciliates (e.g. Landry et al. 1984, Campbell \& Carpenter 1986a, b, Iturriaga \& Mitchell 1986. Iturriaga \& Marra 1988, Weisse 1988, Kudoh et al. 1990, Caron et al. 1991, Kuosa 1991, Sherr et al. 1991, Pick \& Bérubé 1992). Furthermore, using a sensitive chemiluminescence method for $\mathrm{NO}_{3}{ }^{-}$analysis, Glover et al. (1988a, b) found that introduction of ca $10 \mathrm{nM}$ $\mathrm{NO}_{3}{ }^{-}$(below the detection limit of the conventional colorimetric method) to surface waters in the stratified Sargasso Sea was followed by a Synechococcus spp.
(= typical PC) bloom. However, in spite of their pioneering efforts, there are still very few studies dealing with the relationship between the changes in chemical variables (nutrients and trace metals) and PC population dynamics. This is probably due to the high growth rate of PC even in 'nutrient-depleted' (i.e. below the detection limit of conventional methods) waters (e.g. Campbell \& Carpenter 1986a, Iturriaga \& Mitchell 1986, Iturriaga \& Marra 1988) and/or to infrequent (weekly or monthly) monitoring of PC populations, which makes it difficult to relate changes of PC populations with chemical variables.

We have monitored the marine environment around the Ie-shima Islands (Seto Inland Sea, Japan) each summer since 1985 (Fig. 1). This area is usually stratified and nutrient concentrations are very low (e.g. $\leq 0.1 \mu \mathrm{M}$ $\mathrm{NO}_{3}{ }^{-}$) above the thermocline (Nakamura et al. 1988). However, sporadic introduction of nutrients to the surface waters coupled with wind mixing causes diatom 'summer blooms' or red tides due to the raphidophycean flagellate Chattonella antiqua (Nakamura et al. 1989). Furthermore, the PC concentration increased rapidly to 


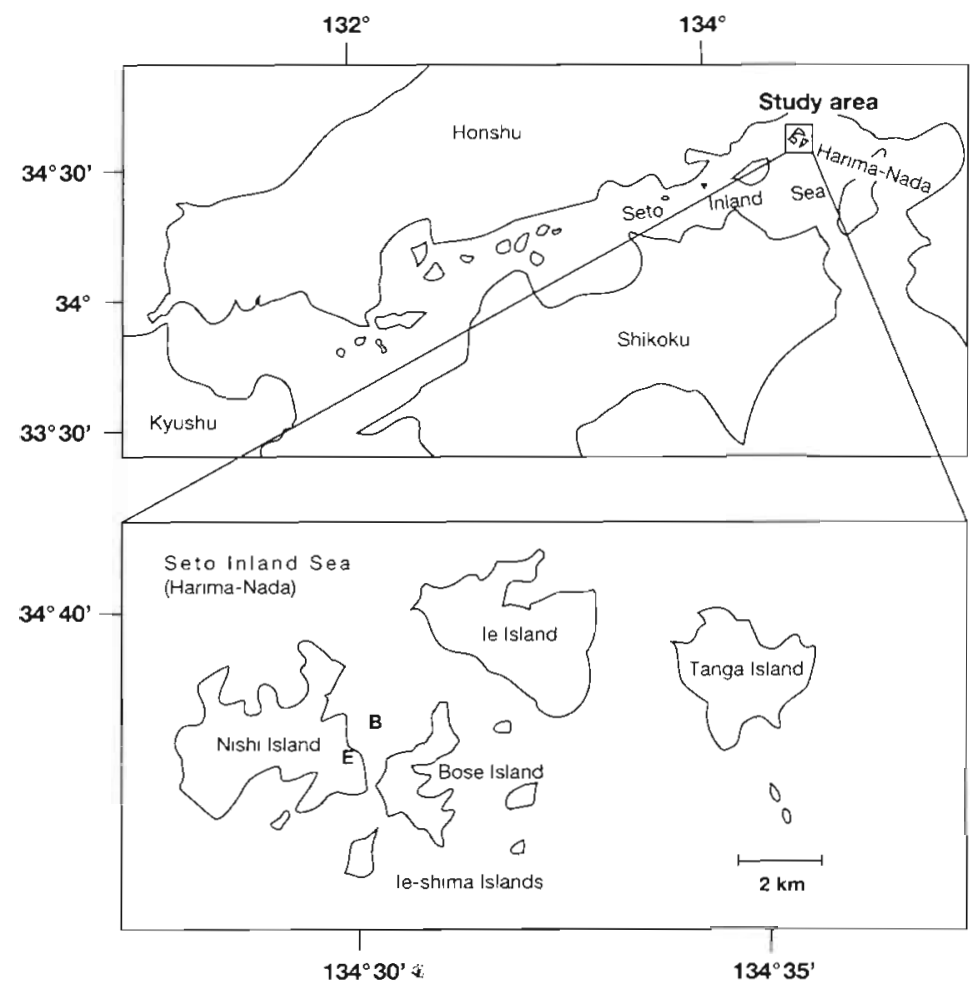

Fig. 1 Sampling station locations around the Ie-shima Islands, Seto Inland Sea. (B) Sampling station; (E) field lab

reach $>1 \times 10^{5} \mathrm{ml}^{-1}$ following strong wind mixing in 1991 (K. Fukami \& Y. Nakamura unpubl.). Based on the above observations, we hypothesized that the introduction of $\mathrm{N}$ - and/or P-nutrients liberated PC from $\mathrm{N}$ and/or P-limitation and that the growth rate of $\mathrm{PC}$ in this coastal area does not reach maximum even at nutrient levels (e.g. 0.1 to $1 \mu \mathrm{M} \mathrm{NO}_{3}{ }^{-}$) higher than the detection limit for conventional colorimetric methods. In order to verify this, and to assess the roles of chemical variables on population dynamics of $\mathrm{PC}$, we monitored temporal and vertical changes in $\mathrm{PC}$ populations together with environmental variables on a daily basis during summer 1992. We also conducted field experiments on PC growth in $<2 \mu \mathrm{m}$ fractions of the seawater enriched with $\mathrm{NO}_{3}^{-}, \mathrm{PO}_{4}{ }^{3-}$, and/or metal buffer solution (composed mainly of $\mathrm{Fe}^{\mathrm{III}}$ and EDTA). In the present paper, results from field observations and experiments are described and the importance of trace metals (rather than $\mathrm{N}$ and $\mathrm{P}$ ) for PC blooming is discussed.

\section{METHODS}

Monitoring of marine environment. In summer 1992 (16 July to 9 August), field surveys were conducted at Stn B (depth $=21 \mathrm{~m}$ ) around the Ie-shima Islands
(Fig. 1). Water temperature, salinity, and dissolved oxygen were monitored at $2.5 \mathrm{~m}$ intervals using a Surveyor Il (Hydrolab Co.). Transparency of the seawater was measured using a Secchi disk. Water samples for chemical analysis $\left(\mathrm{NO}_{3}{ }^{-}, \mathrm{NO}_{2}{ }^{-}, \mathrm{NH}_{4}{ }^{+}, \mathrm{PO}_{4}{ }^{3}, \mathrm{Si}(\mathrm{OH})_{4}\right.$ chlorophyll a) and for enumeration of $\mathrm{PC}$ and HNAN were taken from depths of $0,5,10$ 15 and $19 \mathrm{~m}$ (= for chemical analysis only) using a 101 Van Dorn-type bottle. Monitoring and sampling were conducted daily (except 4 and 8 August due to typhoons) in the morning (06:20 to 07:00 h), and water samples were treated (filtration, fixation, etc.) immediately in our field laboratory (Fig. 1). Analytical procedures for each chemical variable have been summarized in a previous paper (Nakamura et al. 1988)

Field experiments. PC growth experiments in $<2 \mu \mathrm{m}$ fractions were conducted 3 times (Run 1: 22 to 23 July; Run 2: 1 to 3 August; Run 3: 6 to 8 August). Seawater samples were obtained from $5 \mathrm{~m}$ depth in the morning together with routine samples (see above) and poured into a 21 polyporopyrene (PP) bottle. Samples were stored in an incubator, where the temperature was set at that of $5 \mathrm{~m}$ $\left( \pm 1^{\circ} \mathrm{C}\right.$ ) and irradiance was ca $25 \mu \mathrm{E} \mathrm{m} \mathrm{m}^{-2} \mathrm{~s}^{-1}$, until routine treatments were finished (ca 09:30 h). Samples were then filtered through Nuclepore $2 \mu \mathrm{m}$ filters mounted on a polysulfone filtration apparatus ( 1 1, Nalgene Co.) with gentle negative pressure $(<50 \mathrm{~mm} \mathrm{Hg})$. About $400 \mathrm{ml}$ of seawater was filtered through 1 filter (47 $\mathrm{mm}$ diameter). Filtrates were poured into a $2 \mathrm{l}$ PP bottle, then dispensed into glass bottles $(250 \mathrm{ml}$ in volume with $200 \mathrm{ml}$ of sample solution) and received enrichments. Modes of enrichment were: ' $\mathrm{N}+\mathrm{P}$ ' $\left(10 \mu \mathrm{M} \mathrm{NO}_{3}{ }^{-}\right.$and $1 \mu \mathrm{MPO}_{4}{ }^{3-}$, Runs 1, 2 \& 3); 'Metals' $10.3 \mathrm{ml} \mathrm{N}-1$ metal solution (Nakamura \& Umemori 1991) per bottle, Run 3]; 'Full' ( $\mathrm{NO}_{3}^{-}, \mathrm{PO}_{4}{ }^{3-}$ and N-1 metals were added at the same levels of ' $\mathrm{N}+\mathrm{P}$ ' and 'Metals', Runs $2 \& 3$ ); and a control (no addition, Runs 1, $2 \& 3$ ). Added concentrations of trace metals and EDTA through $\mathrm{N}-1$ metal solution were $350 \mathrm{nM}$ $\mathrm{Fe}^{\mathrm{III}}, 5 \mathrm{nM} \mathrm{Co}{ }^{\mathrm{II}}, 63 \mathrm{nM} \mathrm{Zn}{ }^{\text {II }}, 240 \mathrm{nM} \mathrm{Mn}{ }^{\text {II }}, 1 \mathrm{nM} \mathrm{Cu}{ }^{\mathrm{II}}$, $1 \mathrm{nM} \mathrm{MoO}{ }_{4}{ }^{2-}$ and $4 \mu \mathrm{M}$ EDTA. In parallel with enrichment, a sample $(100 \mathrm{ml})$ for enumeration of PC and HNAN was also taken from the $<2 \mu \mathrm{m}$ filtrates. Filtration apparatus, filters and glass bottles (presterilized by autoclaving) were rinsed thoroughly by $\mathrm{GF} / \mathrm{F}$ filtered seawater (from $5 \mathrm{~m}$ ) before use. The bottles which had received enrichment were then suspended at $5 \mathrm{~m}$ depth (around 1.1:00 h) and the growth of PC was monitored for 1 (Run 1) or $2 \mathrm{~d}$ (Runs 2 $\& 3)$. The bottles were recovered, subsamples (15 $\mathrm{ml})$ 
were withdrawn and fixed at intervals of 21 to $24 \mathrm{~h}$ These experiments were conducted in duplicate.

Enumeration. Samples for PC (and HNAN) counts were fixed with glutaraldehyde (final concentration $1 \%)$, stored in a refrigerator $\left(5^{\circ} \mathrm{C}\right)$, and enumerated within 2 d after sampling. Subsamples $(3 \mathrm{ml})$ were concentrated on black $0.2 \mu \mathrm{m}$ Nuclepore filters under low vacuum (ca $100 \mathrm{~mm} \mathrm{Hg}$ ). The filters were examined by epifluorescence microscopy using a Nikon Optiphot-2 equipped with a $\mathrm{Hg} 100 \mathrm{~W}$ lamp and B2 filter cassette (exciter 450 to $490 \mathrm{~nm}$, dichroic mirror $510 \mathrm{~nm}$, barrier $520 \mathrm{~nm}$. PC were characterized by bright yellow to orange fluorescence. It should be noted that the PC detected in the present study were cells containing phycoerythrin, since we used 'blue excitation' only (cf. Pick 1991). PC cells were counted at $1250 \times$ using a fluor 100/1.30 oil objective by observing at least 50 and 80 fields $(80 \times 80 \mu \mathrm{m})$ in natural and experimental samples, respectively. Using $30 \mathrm{ml}$ of subsamples, we also enumerated HNAN by 4',6-diamidino-2-phenylindole (DAPI) staining, details of which will be described in another article.

\section{RESULTS}

\section{Temporal changes in environmental variables}

Vertical profiles of environmental variables throughout the survey period are summarized in Table 1 and Fig. 2A to D. Water was weakly stratified between 16 and 22 July and strong stratification developed between 23 and 28 July due to calm and sunny weather. After 29 July, weather was still sunny, but a continuous westward-blowing wind weakened the stratification.
The typhoon (No. 9) on 4 August destroyed the stratification completely (Fig. 2A).

A significant increase of $\mathrm{NO}_{3}^{-}$(and $\mathrm{PO}_{4}{ }^{3-}$ ) concentration in the surface layer $(0$ to $5 \mathrm{~m}$ ) was observed on 19 July (Fig. 2B, C) due to the strong winds on 18 July. This increase caused a bloom of diatoms (see below) and $\mathrm{NO}_{3}{ }^{-}$in the surface layer then decreased rapidly to below the detection limit $(0.1 \mu \mathrm{M})$. After 30 July, $\mathrm{NO}_{3}^{-}$concentrations in the surface layer increased again, coupled with the weakening of thermal stratification. The concentration of $\mathrm{NH}_{4}^{+}$in the surface layer was usually below $0.2 \mu \mathrm{M}$ before 3 August, but after that it increased to a maximum of $3 \mu \mathrm{M}$. Changes in $\mathrm{PO}_{4}{ }^{3-}$ concentration were similar to those of $\mathrm{NO}_{3}{ }^{-}$, but $\mathrm{PO}_{4}{ }^{3-}$ was not depleted completely (detection limit $=0.01 \mu \mathrm{M}$ ) except for 25 and 27 July ( 0 to $5 \mathrm{~m}$ ).

Following the introduction of nutrients to the surface layer on 19 July, chlorophyll a concentrations (0 to $5 \mathrm{~m}$ ) increased rapidly to reach $4 \mu \mathrm{g} \mathrm{l}^{-1}$ (20 to $22 \mathrm{July,} \mathrm{Fig.}$ 2D) due to a bloom of diatoms (Chaetoceros spp.). The dense layer of chlorophyll a was then shifted downward (23 to 29 July), apparently due to the sinking of diatoms. After 30 July, nutrients were introduced again to the surface layer, but chlorophyll a did not increase significantly.

\section{Temporal changes in PC cell concentrations}

PC cells in the study area were dominated by spherical cells ( $c$ a $70 \%$ of total $P C$ ) ranging in size from 0.8 to $1.4 \mu \mathrm{m}$ diameter, and the rest were rod-shaped Synechoccocus-type cells $(0.8$ to $1.0 \times 1.0$ to $1.6 \mu \mathrm{m})$. Irregular clumps of $\mathrm{PC}$ were rare throughout the survey period.

Table 1. Vertical profiles of environmental variables at Stn B from 16 July to 9 August 1992. Secchi depth during this period changed from 3 to $10.5 \mathrm{~m}$ (avg. $=7.2 \mathrm{~m}$ ). Values in parentheses are averages of each parameter throughout the survey period DO: dissolved oxygen

\begin{tabular}{|c|c|c|c|c|c|c|c|c|c|}
\hline $\begin{array}{l}\text { Depth } \\
(\mathrm{m})\end{array}$ & $\begin{array}{l}\text { Temp. } \\
\left({ }^{\circ} \mathrm{C}\right)\end{array}$ & $\begin{array}{c}S \\
(\% 0)\end{array}$ & $\begin{array}{c}\text { DO } \\
(\mathrm{ppm})\end{array}$ & $\begin{array}{l}\mathrm{NO}_{3}^{-} \\
(\mu \mathrm{M})\end{array}$ & $\begin{array}{l}\mathrm{NO}_{2}^{-} \\
\left(\mu \mathrm{M}^{-}\right)\end{array}$ & $\begin{array}{l}\mathrm{NH}_{4}^{+} \\
(\mu \mathrm{M})\end{array}$ & $\begin{array}{l}\mathrm{PO}_{4}^{3-} \\
(\mu \mathrm{M})\end{array}$ & $\begin{array}{c}\mathrm{Si}(\mathrm{OH})_{4} \\
(\mu \mathrm{M})\end{array}$ & $\begin{array}{c}\text { Chl a } \\
\left(\mu \mathrm{gl}^{-1}\right)\end{array}$ \\
\hline 0 & $\begin{array}{c}22.0-25.7 \\
(24.0)\end{array}$ & $\begin{array}{c}29.0-32.4 \\
(31.4)\end{array}$ & $\begin{array}{c}6.0-8.6 \\
(7.3)\end{array}$ & $\begin{array}{c}<0.1-1.7 \\
(0.4)\end{array}$ & $\begin{array}{c}<0.1-0.4 \\
\quad(0.1)\end{array}$ & $\begin{array}{c}<0.2-2.9 \\
(0.3)\end{array}$ & $\begin{array}{c}<0.01-0.55 \\
(0.13)\end{array}$ & $\begin{array}{c}1.5-17.1 \\
(7.1)\end{array}$ & $\begin{array}{c}0.6-4.1 \\
(1.6)\end{array}$ \\
\hline 5 & $\begin{array}{c}21.8-25.1 \\
(23.6)\end{array}$ & $\begin{array}{c}31.6-32.4 \\
(32.0)\end{array}$ & $\begin{array}{c}5.8-8.6 \\
(6.9)\end{array}$ & $\begin{array}{c}<0.1-1.8 \\
(0.5)\end{array}$ & $\begin{array}{c}<0.1-0.5 \\
\quad(0.2)\end{array}$ & $\begin{array}{c}<0.2-2.9 \\
(0.3)\end{array}$ & $\begin{array}{c}<0.01-0.55 \\
(0.16)\end{array}$ & $\begin{array}{c}2.0-16.2 \\
(7.6)\end{array}$ & $\begin{array}{c}0.8-3.8 \\
(1.8)\end{array}$ \\
\hline 10 & $\begin{array}{c}21.5-24.3 \\
(22.6)\end{array}$ & $\begin{array}{c}31.9-32.6 \\
(32.3)\end{array}$ & $\begin{array}{c}5.2-8.0 \\
(6.2)\end{array}$ & $\begin{array}{c}<0.1-3.4 \\
(1.5)\end{array}$ & $\begin{array}{c}<0.1-1.1 \\
(0.4)\end{array}$ & $\begin{array}{c}<0.2-2.5 \\
(0.3)\end{array}$ & $\begin{array}{c}<0.01-0.50 \\
(0.24)\end{array}$ & $\begin{array}{c}2.2-18.2 \\
(10.8)\end{array}$ & $\begin{array}{c}1.3-4.1 \\
(2.4)\end{array}$ \\
\hline 15 & $\begin{array}{c}20.3-23.9 \\
(21.8)\end{array}$ & $\begin{array}{c}32.1-32.7 \\
(32.4)\end{array}$ & $\begin{array}{c}4.0-6.0 \\
(5.2)\end{array}$ & $\begin{array}{c}1.2-5.8 \\
(3.3)\end{array}$ & $\begin{array}{c}0.3-1.8 \\
(0.9)\end{array}$ & $\begin{array}{c}<0.2-2.1 \\
(0.6)\end{array}$ & $\begin{array}{c}0.20-0.71 \\
(0.50)\end{array}$ & $\begin{array}{c}9.5-26.8 \\
(17.9)\end{array}$ & $\begin{array}{c}1.5-6.6 \\
(2.5)\end{array}$ \\
\hline 19 & $\begin{array}{c}20.1-23.8 \\
(21.3)\end{array}$ & $\begin{array}{c}32.3-32.7 \\
(32.5)\end{array}$ & $\begin{array}{c}3.5-5.8 \\
(4.6)\end{array}$ & $\begin{array}{c}1.6-7.8 \\
(4.9)\end{array}$ & $\begin{array}{c}0.5-1.8 \\
(1.2)\end{array}$ & $\begin{array}{c}<0.2-2.1 \\
\quad(0.8)\end{array}$ & $\begin{array}{c}0.34-0.89 \\
(0.67)\end{array}$ & $\begin{array}{c}13.1-30.3 \\
(23.5)\end{array}$ & $\begin{array}{c}1.4-6.3 \\
(2.5)\end{array}$ \\
\hline $\begin{array}{c}21 \\
\text { (bottom) }\end{array}$ & $\begin{array}{c}20.0-23.8 \\
(21.2)\end{array}$ & $\begin{array}{c}32.4-32.9 \\
(32.6)\end{array}$ & $\begin{array}{c}3.3-5.7 \\
(4.3)\end{array}$ & & & & & & \\
\hline
\end{tabular}



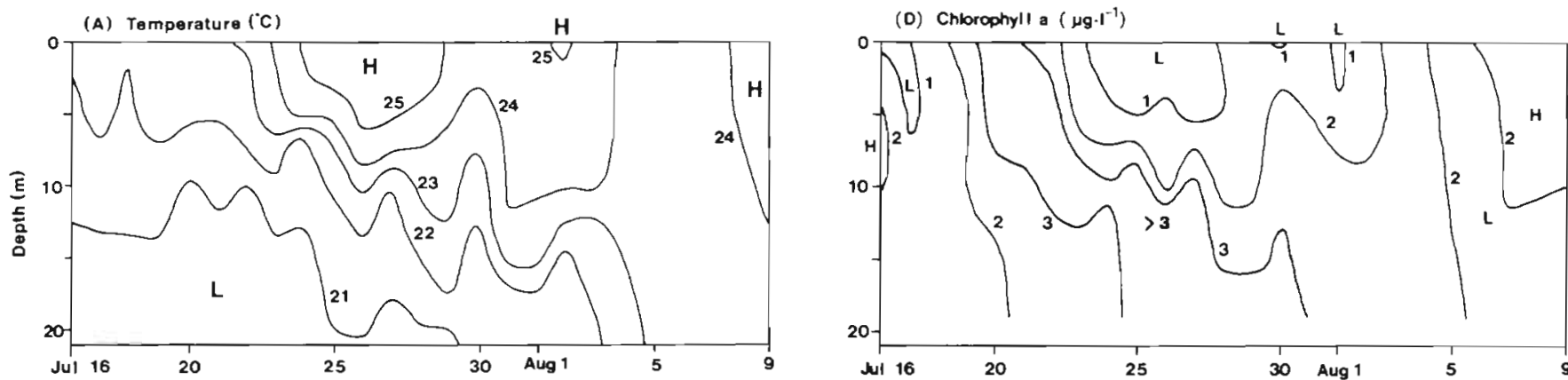

(B) $\mathrm{NO}_{3}^{-}(\mu \mathrm{M})$

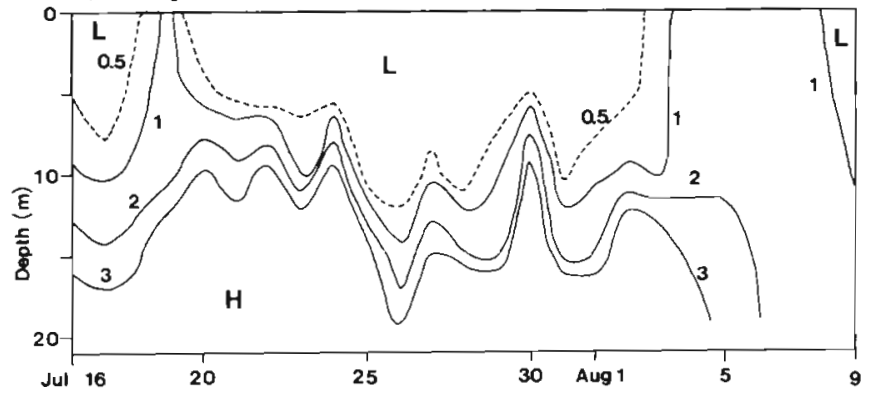

(E) Picacyanobecteria $\left(\times 10^{4} \mathrm{ml}^{-1}\right)$

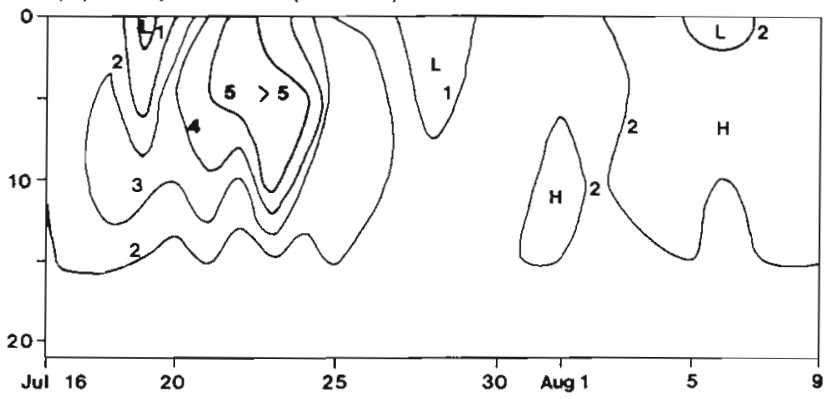

(C) $\mathrm{PO}_{4}^{3-(\mu \mathrm{M})}$

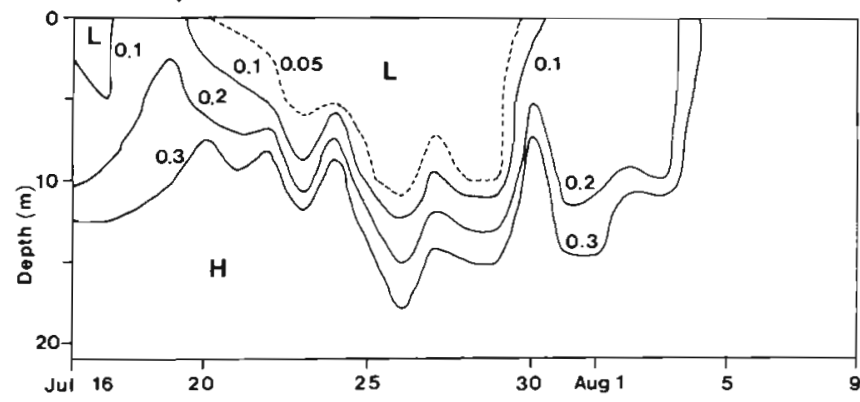

Fig. 2. Temporal and vertical variations of (A) temperature $\left({ }^{\circ} \mathrm{C}\right),(\mathrm{B})$ nitrate $(\mu \mathrm{M}),(\mathrm{C})$ phosphate $(\mu \mathrm{M})$, (D) chlorophyll a $\left(\mu \mathrm{g} \mathrm{I}^{-1}\right)$ and $(\mathrm{E})$ picocyanobacteria $\left(\times 10^{4} \mathrm{ml}^{-1}\right)$. H: high; L: low

$F$-values averaged over the survey period were 17,17 , 12 and $8 \%$ for $0,5,10$ and $15 \mathrm{~m}$ depth, respectively $F$-values higher than $40 \%$ were observed in the surface layer $(0$ to $5 \mathrm{~m})$ at the time when diatom-rich layer shifted downward and PC were still blooming (i.e. 23 to 24 July).

Temporal changes in $\mathrm{PC}$ concentration $\left(N_{\mathrm{PC}}\right)$ are shown in Fig. 2E and $N_{\mathrm{PC}}$ were in the range of 0.7 to $5.7 \times 10^{4} \mathrm{ml}^{-1}$ during the survey period. Following the introduction of nutrients to the surface layer ( 0 to $5 \mathrm{~m}$ ) on 19 July (Figs. 2B \& 3), $N_{\mathrm{PC}}$ increased rapidly, especially in the surface layer, and $N_{P C}$ averaged over 0 to $15 \mathrm{~m}$ depth reached a maximum $\left(4.8 \times 10^{4} \mathrm{ml}^{-1}\right)$ on 23 July (Fig. 3). $N_{p C}$ then decreased during a strong thermal stratification period (23 to $28 \mathrm{July}$ ). In contrast to the chlorophyll a change (Fig. 2D), the dense layer of PC did not shift downward (Fig. 2E) apparently due to the slow sinking rate of PC. Although $N_{\mathrm{PC}}$ increased again coupled with weakening of thermal stratification (after 29 July), its rate of increase was rather slow (Fig. 3).

Cell concentrations of PC were converted to chlorophyll a assuming a $\mathrm{PC}$ cell diameter of $1.2 \mu \mathrm{m}$ and

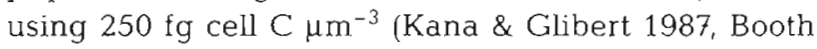
1988) and a C: chl a ratio of 22.5 (Takahashi et al. 1985, Geider 1987, Ray et al. 1989). The contribution of PC to total chlorophyll a $(F)$ was in the range of 3 to $63 \%$.

Concentrations of eukaryotic picoalgae $\left(N_{\mathrm{EPA}}\right)$ were also monitored at depths of 5 and $15 \mathrm{~m}$, and $N_{\text {EPA }}: N_{P C}$

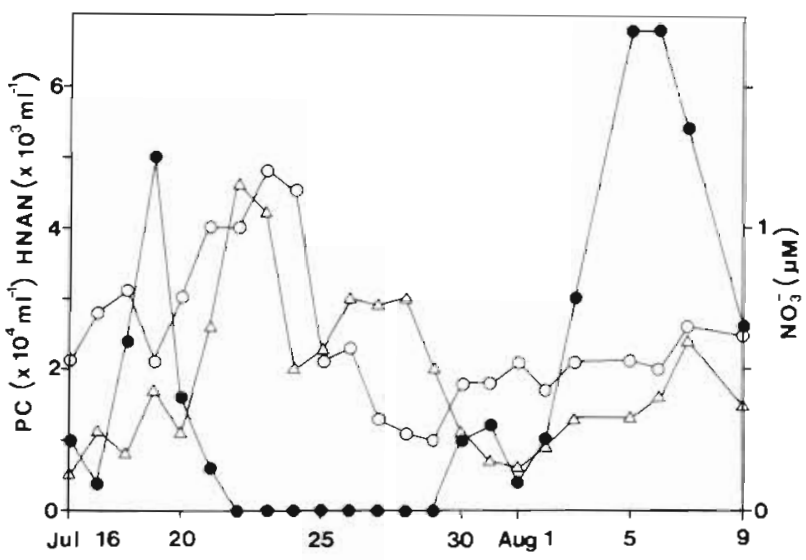

Fig. 3. Temporal variations of nitrate $(\bullet$ averaged over 0 to $5 \mathrm{~m})$, picocyanobacteria $(0$; averaged over 0 to $15 \mathrm{~m})$ and heterotrophic nanoflagellates ( $\Delta$; averaged over 0 to $15 \mathrm{~m}$ ) 
ratios averaged over the survey period were 14 and $15 \%$ for 5 and $15 \mathrm{~m}$ depth, respectively.

\section{Field experiments}

Initial conditions for the 3 experiments are summarized in Table 2, and growth curves of $\mathrm{PC}$ in each run are shown in Fig. $4 \mathrm{~A}$ to $\mathrm{C}$. In Run 1 (Fig. $4 \mathrm{~A}$ ) where $\mathrm{NO}_{3}{ }^{-}$and $\mathrm{NH}_{4}{ }^{+}$were below the detection limit, $N_{\mathrm{PC}}$ in the control and ' $\mathrm{N}+\mathrm{P}^{\prime}$-enrichment decreased after $24 \mathrm{~h}$ incubation. However, the rate of decrease in ' $N+P^{\prime}$ was lower than in the control, and PC cells in ' $\mathrm{N}+\mathrm{P}$ ' showed much brighter fluorescence than in the control after incubation. In Run 2 (Fig. 4B), where $\mathrm{NO}_{3}{ }^{-}$(and $\mathrm{PO}_{4}{ }^{3-}$ ) were not completely depleted, $N_{\mathrm{PC}}$ in the control and ' $\mathrm{N}+\mathrm{P}^{\prime}$-enrichment increased significantly during $48 \mathrm{~h}$ incubation. Although a slight lag was observed $(0$ to 24 h), the growth rates of PC in the control and ' $N+P$ 'enrichment between 24 and 48 h reached 0.87 and 0.80 $\mathrm{d}^{-1}$, respectively. The growth of $\mathrm{PC}$ in 'Full'-enrichment was more rapid than in the control and ' $N+\mathrm{P}^{\prime}$ enrichment, and the growth rate between 24 and $48 \mathrm{~h}$ was $1.26 \mathrm{~d}^{-1}$. In Run 3 (Fig. 4C), where $\mathrm{N}$ - and $\mathrm{P}$ -

Table 2. Initial conditions for PC growth experiments

\begin{tabular}{|lccc|}
\hline & $\begin{array}{c}\text { Run 1 } \\
\text { (22 to 23 July) }\end{array}$ & $\begin{array}{c}\text { Run 2 } \\
\text { (1 to 3 August) }\end{array}$ & $\begin{array}{c}\text { Run 3 } \\
\text { (6 to 8 August) }\end{array}$ \\
\hline Temp. $\left({ }^{\circ} \mathrm{C}\right)$ & 22.7 & 24.6 & 23.5 \\
Salinity $(\%)$ & 32.1 & 32.0 & 32.4 \\
$\mathrm{NO}_{3}{ }^{-}(\mu \mathrm{M})$ & $<0.1$ & 0.1 & 1.8 \\
$\mathrm{NO}_{2}{ }^{-}(\mu \mathrm{M})$ & $<0.1$ & 0.1 & 0.5 \\
$\mathrm{NH}_{4}{ }^{+}(\mu \mathrm{M})$ & $<0.2$ & $<0.2$ & 0.8 \\
$\mathrm{PO}_{4}{ }^{3-}(\mu \mathrm{M})$ & 0.06 & 0.12 & 0.41 \\
$\mathrm{HNAN}^{-1}\left(\mathrm{ml}^{-1}\right)^{\mathrm{a}}$ & $1.2 \times 10^{3}$ & $<0.1 \times 10^{3}$ & $0.2 \times 10^{3}$ \\
${ }^{\text {a Concentration in }}<2 \mu \mathrm{m}$ filtrates \\
\hline
\end{tabular}

(A) Run 2

(B) Run 3
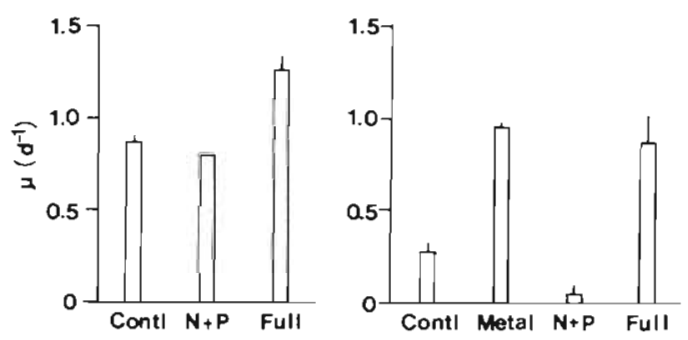

Fig. 5. Effects of N-, P- and metal buffer-enrichment on the growth rates $(\mu)$ of picocyanobacteria. (A) Run 2: 1 to 3 August; (B) Run 3:6 to 8 August. Vertical error bars show the range of duplicate experiments

nutrients were at a sufficient level, $N_{\mathrm{PC}}$ in the control and ' $N+P^{\prime}$-enrichment did not increase significantly between 0 and $22 \mathrm{~h}$, and the growth rates in these modes between 22 and $43 \mathrm{~h}$ were below $0.3 \mathrm{~d}^{-1}$. Although growth of PC in 'Metals'- and 'Full'-enrichment showed a lag between 0 and $22 \mathrm{~h}$, it was rapid between 22 and $43 \mathrm{~h}$. The growth rates during this period were 0.95 and $0.88 \mathrm{~d}^{-1}$ for 'Metals'- and 'Full'enrichment, respectively. The growth rates obtained in Run 2 (24 to $48 \mathrm{~h}$ ) and Run 3 (22 to $43 \mathrm{~h}$ ) are summarized in Fig. 5

\section{DISCUSSION}

Coupled with the first mixing event on $19 \mathrm{July}, N_{\mathrm{PC}}$ increased rapidly to reach ca $5 \times 10^{4} \mathrm{ml}^{-1}$ (Fig. 3). However, the next mixing after 30 July did not cause a PC bloom. Enrichment experiments conducted in the second mixing period showed enhancement of $\mathrm{PC}$ growth by addition of metal buffer solution. These results suggest that chemical variable(s) can control the population of PC even in a eutrophic inland sea (cf. Glover et al. 1988a, b).
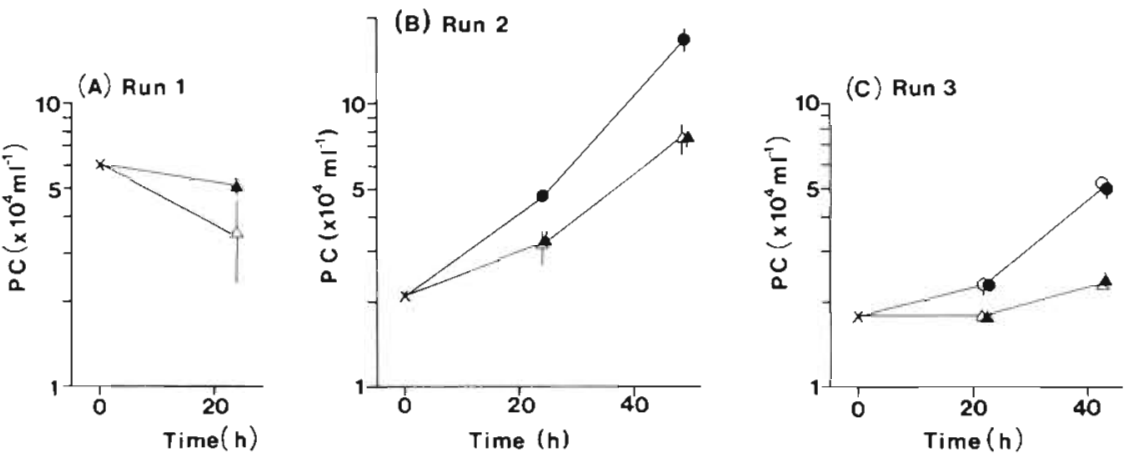

Fig. 4. Growth curve of picocyanobacteria in $<2 \mu \mathrm{m}$ seawater fraction for (A) Run 1 : 22 to 23 July; (B) Run 2: 1 to 3 August; (C) Run 3: 6 to 8 August. ( $\triangle$ ) Control; (A) N+P, $\mathrm{NO}_{3}{ }^{-}$and $\mathrm{PO}_{4}{ }^{3-}$ added; (O) Metals, $\mathrm{N}-1$ metal solution added; ( $\bullet$ Full, $\mathrm{NO}_{3}{ }^{-}, \mathrm{PO}_{4}{ }^{3-}$ and $\mathrm{N}-1$ metals added. Vertical error bars show the range of duplicate counts

\section{Field observations}

It has often been pointed out that the abundance of $\mathrm{PC}$ is positively correlated with temperature (e.g. Caron et al. 1985, Murphy \& Haugan 1985, El Hag \& Fogg 1986, Kuosa 1991). However, this was not the case in the present study, since PC was abundant (3.9 to $5.0 \times$ $10^{4} \mathrm{ml}^{-1} ; 0$ and $5 \mathrm{~m}$ ) on 21 July when the corresponding temperature was still in the range 22.1 to $22.9^{\circ} \mathrm{C}$ and the lowest abun- 
dance of PC (27 to 29 July; Fig. 3) coincided with the highest temperature period $\left(24.2\right.$ to $25.5^{\circ} \mathrm{C}$; 0 and $5 \mathrm{~m}$ ). Furthermore, PC bloomed when the surface temperature was 24.0 to $26.3^{\circ} \mathrm{C}$ in summer 1991 (K. Fukami \& Y. Nakamura unpubl.). Thus we conclude that the abundance of PC was not significantly affected by temperature in the range $\left(22\right.$ to $\left.26^{\circ} \mathrm{C}\right)$ encountered in both years.

Among the processes of PC loss, grazing by HNAN and/or ciliates is considered to be most important (reviewed by Stockner 1988). During the period of decreasing PC (23 to 27 July), cell concentrations of HNAN ( $N_{\text {HNAN }}$ ) remained relatively high in comparison with those of the pre-bloom period (16 to $19 \mathrm{July}$ ) or the second mixing period (after 30 July; Fig. 3). HNAN cells containing PC cells inside them were also observed ( $>10 \%$ of the total by impression, not quantitative). These observations suggest that the high abundance of HNAN contributed, to some extent, to the disappearence of the PC bloom. However, it should be noted that grazing by ciliates or viral lysis of PC cells (Porter \& Fuhrman 1990, Suttle et al. 1990) might also have played significant roles in the mortality of PC.

The second mixing period (after 30 July) was characterized by high concentrations of $\mathrm{N}$ - and P-nutrients in the surface layer, low abundance of HNAN (Fig. 3) and high transparency of the seawater ( 7.5 to $11 \mathrm{~m}$ from 30 July to 3 August). $N_{\text {HNAN }}$ in this period was comparable to that observed during the PC bloom period in summer 1991 (K. Fukami \& Y. Nakamura unpubl.). These conditions seem to be favorable for PC blooming. However, the increase of $N_{\mathrm{PC}}$ during this period was not rapid in comparison with the bloom period (Fig. 3). These observations suggest that the population of PC was controlled by factors such as trace metals (see below) and/or ciliates (not monitored in both years), and not by $N$ - and P-nutrients, HNAN, light or temperature.

\section{Chemical variables affecting PC growth}

Before the field survey of 1992, we hypothesized that addition of $\mathrm{N}$ - and $\mathrm{P}$-nutrients would enhance the growth of PC (see 'Introduction'). In this context the field experiment of Run 1 (22 to 23 July) was conducted only in the control and ' $N+P^{\prime}$-enrichment modes. However, $N_{P C}$ in both modes decreased during $24 \mathrm{~h}$ incubation. (Fig. 4A) and this suggested to us the addition of a metal buffer solution in Run 2 (1 to 3 August) and Run 3 ( 6 to 8 August). The reason for the decrease of $N_{\mathrm{PC}}$ in Run 1 is still uncertain. HNAN slightly contaminated the $<2 \mu \mathrm{m}$ fraction $(1.2$ $\times 10^{3} \mathrm{ml}^{-1} ; 30 \%$ of original seawater) and may have suppressed the increase of $N_{\mathrm{PC}}$ to some extent. However, $N_{P C}$ of the natural population increased under $N_{\text {HNAN }}$ of $2.5 \times 10^{3} \mathrm{ml}^{-1}(21 \mathrm{July}$, Fig. 3) and the decrease of $N_{P C}$ in Run 1 cannot be explained by the contamination of HNAN alone. $N_{\text {HNAN }}$ in Runs 2 \& 3 were $\leq 0.2 \times 10^{3} \mathrm{ml}^{-1}$ and probably had a minor effect on $\mathrm{PC}$ growth.

\section{Effects of metal buffer solution}

The most striking feature of the results obtained in the present study was the enhancement of PC growth by addition of the metal buffer solution (Fig. 5). Since we did not expect this effect before the survey, a clean technique (Fitzwater et al. 1982) was not used, and thus it might be considered that the growth stimulation was due to an experimental artifact. However, based on our previous results obtained from field observations and experiments (Nakamura et al. 1989, Nakamura 1990), we infer that the growth stimulation was due to $\mathrm{Fe}$ deficiency of natural PC populations, as discussed below.

A possible explanation of the growth enhancement by metal buffer solution is that toxic metals (such as $\mathrm{Cu}$ ) already present in natural seawater or as contaminants from experimental procedures suppressed the growth of $\mathrm{PC}$ in the control and ' $\mathrm{N}+\mathrm{P}$ '-enrichment, and that the enrichment of EDTA through the metal buffer solution liberated PC from growth suppression. However, in the study area in the summers of 1986 to 1988 (Nakamura 1990), Cu (ca $10 \mathrm{nM}$ in $0.8 \mu \mathrm{m}$ filtrates) was highly chelated by natural organic ligand(s), pCu (-log of cupric ion activity) was in the range 11.5 to 11.7 (= non-toxic range for all phytoplankton species examined; Gavis et al. 1981), Cucomplexing capacity was ca $100 \mathrm{nM}$, and addition of inorganic $\mathrm{Cu}(60 \mathrm{nM})$ to natural seawater did not have any toxic effects on the growth of Chattonella antiqua (= Raphidophyceae, a species sensitive to cupric ion activity; Nakamura et al. 1986). Furthermore, in our experiments to determine the in situ growth rate of $C$. antiqua (Nakamura et al. 1989), the experimental procedures (sampling, filtration apparatus, incubation bottles) were essentially the same as those in the present study, and the obtained growth rates could be explained satisfactorily by the ambient concentrations of $\mathrm{N}$ - and P-nutrients alone (cf. Nakamura et al. 1988) without any deleterious effects of contaminants. Thus it is unlikely that the growth enhancement of PC was due to the detoxification of toxic metals by EDTA.

Another explanation of the growth enhancement mechanism is the adsorption of essential metals (such as $\mathrm{Fe}$ ) to incubation bottles (Fitzwater et al. 1982). Metals might have been scavenged by adsorp- 
tion in the control and ' $\mathrm{N}+\mathrm{P}$ '-enrichment, and the growth of $\mathrm{PC}$ might have been suppressed. However, based on our experiments (Nakamura 1990), adsorption of $\mathrm{Fe}$ in filtered seawater (intitial concentration $=10 \mathrm{nM}$ ) to borosilicate flasks was ca $10 \%$ during $4 \mathrm{~d}$ incubation $\left(25^{\circ} \mathrm{C}, 150 \mu \mathrm{E} \mathrm{m} \mathrm{m}^{-2} \mathrm{~s}^{-1}, 12 \mathrm{~h}\right.$ light $: 12 \mathrm{~h}$ dark cycle). The insignificance of $\mathrm{Fe}$ adsorption to glass bottles was also indicated by Takeda \& Kamatani (1989).

We monitored the $\mathrm{Fe}$ concentration (in $0.8 \mu \mathrm{m}$ filtrates) and conducted growth bioassay experiments in the present study area taking care to avoid trace metal contamination during the summers of 1986 to 1988 (Nakamura 1990). The results indicated that Fe in the seawater was usually insufficient to support the maximum growth rate of Chattonella antiqua in spite of the relatively high concentration of Fe (4 to $10 \mathrm{nM}$ ). Furthermore, Brand (1991) indicated that Fe demand by $\mathrm{PC}$ (assessed by $\mathrm{Fe} / \mathrm{P}$ ratios inside the cell) was much higher $\left(>10^{1.3}\right.$ ) than for oceanic species of eukaryotic phytoplankton and comparable to a raphidophycean flagellate Heterosigma akasiwo (closely related to $C$. antiqua in taxonomic and physiological aspects; Watanabe et al. 1982, Nakamura \& Watanabe 1983). Based on the above arguments, it seems resonable to infer that growth enhancement of $\mathrm{PC}$ by addition of the metal buffer solution was due to insufficient $\mathrm{Fe}$ in the original seawater and not to an experimental artifact, although growth stimulation by other metals (such as Mn) cannot be ruled out.

\section{Nitrogen and phosphorus}

In order to assess the roles of $\mathrm{N}$ - and P-nutrients on the growth of PC, growth rates between 'Metals'- and 'Full'-enrichment (i.e. both modes are set at 'optimum' for trace metals) should (ideally) be compared, since trace metals enhanced the growth significantly (Fig. 5). Unfortunately, the growth in 'Metals' was examined only in Run 3. In this case, the initial ambient nutrient concentrations were very high (Table 2) and it is not surprising that the growth rates in 'Metals' were comparable with those in 'Full'. On the other hand, Run 2 was conducted under the conditions that initial concentration of $\mathrm{NO}_{3}{ }^{-}$was at the detection limit $(0.1 \mu \mathrm{M})$ and the growth rate in the control was $70 \%$ of that in 'Full'. This indicates that $0.1 \mu \mathrm{M} \mathrm{NO}{ }^{-}$can support $>70 \%$ of the maximum growth rate of $\mathrm{PC}$ and the halfsaturation constant for growth is well below $0.1 \mu \mathrm{M}$ $\mathrm{NO}_{3}{ }^{-}$. Thus, although PC populations in 'nutrientdepleted' waters (e.g. 22 to 29 July, 0 to $5 \mathrm{~m}$; Fig. 2B) might have been controlled by $\mathrm{NO}_{3}{ }^{-}$(and/or $\mathrm{PO}_{4}{ }^{3-}$ ), our initial hypothesis that introduction of nutrients (e.g. 0.1 to $1 \mu \mathrm{M} \mathrm{NO}_{3}{ }^{-}$) to the surface layer liberates the PC populations from $\mathrm{N}$ - (and/or P-) limitations (see 'Introduction') is not realistic.

In summary, the results obtained in the present study strongly suggest that trace metal(s) play important roles in the wax and wane of $\mathrm{PC}$ populations. However, questions still remain: what is the difference between the 2 mixing events? Or in other words, were sufficient trace metals introduced in the first event, but not in the second event? Since we did not monitor trace metal concentrations (especially available Fe; see Wells et al. 1991), we cannot answer the above questions at present. Finally, we stress here the importance of trace metal monitoring for full understanding of PC population dynamics.

\section{LITERATURE CITED}

Booth, B. C. (1988). Size classes and major taxonomic groups of phytoplankton at two locations in the subarctic Pacific Ocean in May and August, 1984. Mar. Biol. 97: 275-286

Brand, L. E. (1991). Minimum iron requirements of marine phytoplankton and the implications for the biogeochemical control of new production. Limnol. Oceanogr. 36: $1756-1771$

Campbell, L., Carpenter, E. J. (1986a). Diel patterns of cell division in marine Synechococcus spp. (Cyanobacteria): use of the frequency of dividing cells technique to measure growth rate. Mar. Ecol. Prog. Ser. 32: 139-148

Campbell, L., Carpenter, E. J. (1986b). Estimating the grazing pressure of heterotrophic nanoplankton on Synechococcus spp. using the seawater dilution and selective inhibitor techniques. Mar. Ecol. Prog. Ser. 33: 121-129

Caron, D. A., Lim, E. L., Miceli, G., Waterbury, J. B., Valois, F. W. (1991). Grazing and utilization of chroococcoid cyanobacteria and heterotrophic bacteria by protozoa in laboratory cultures and a coastal plankton community. Mar. Ecol. Prog. Ser. 76: 205-217

Caron, D. A., Pick, F. R., Lean, D. R. S. (1985). Chroococcoid cyanobacteria in Lake Ontario: vertical and seasonal distributions during 1982. J. Phycol. 21: 171-175

El Hag, A. G. D., Fogg, G. E. (1986). The distribution of coccoid blue-green algae (Cyanobacteria) in the Menai Straits and the Irish Sea. Br. Phycol. J. 21: 45-54

Fitzwater, S. E., Knauer, G. A., Martin, J. H. (1982). Metal contamination and its effect on primary production measurements. Limnol Oceanogr. 27: 544-551

Gavis, J., Guillard, R. R. L., Woodward, B. L. (1981). Cupric ion activity and the growth of phytoplankton clones isolated from different marine environments. J. mar. Res. 39: $315-333$

Geider, R. J. (1987). Light and temperature dependence of the carbon to chlorophyll a ratio in microalgae and cyanobacteria: implications for physiology and the growth of phytoplankton. New Phytol. 106: 1-34

Glover, H. E., Prézelin, B. B., Campbell, L., Wyman, M. (1988a). Pico- and ultraplankton Sargasso Sea communities: variability and comparative distributions of Synechococcus spp. and algae. Mar. Ecol. Prog. Ser. 49: $127-139$

Glover, H. E., Prézelin, B. B., Campbell, L., Wyman, M., Garside, C. (1988b). A nitrate-dependent Synechococcus bloom in surface Sargasso Sea water. Nature 331: 161-163 
Iturriaga, R, Marra, J. (1988). Temporal and spatial variability of chroococcoid cyanobacteria Synechococcus spp. specific growth rates and their contribution to primary production in the Sargasso Sea. Mar. Ecol. Prog. Ser. 44: 175-181

Iturriaga, R., Mitchell, B. G. (1986). Chroococcoid cyanobacteria: a significant component in the food web dynamics of the open ocean. Mar. Ecol. Prog. Ser. 28: 291-297

Johnson, P. W., Sieburth, J. McN. (1979). Chroococcoid cyanobacteria in the sea: a ubiquitous and diverse phototrophic biomass. Limnol. Oceanogr. 24: 928-935

Kana, T. M., Glibert, P. M. (1987). Effect of irradiances up to $2000 \mu \mathrm{E} \mathrm{m}^{-2} \mathrm{~s}^{-1}$ on marine Synechococcus WH7803. I. Growth, pigmentation, and cell composition. Deep Sea Res. 34: 479-495

Kudoh, S., Kanda, J., Takahashi, M. (1990). Specific growth rates and grazing mortality of chroococcoid cyanobacteria Synechococcus spp. in pelagic surface waters in the sea J. exp. mar. Biol. Ecol. 142: 201-212

Kuosa, H. (1991). Picoplanktonic algae in the northern Baltic Sea: seasonal dynamics and flagellate grazing. Mar. Ecol. Prog. Ser. 73: 269-276

Landry, M. R., Haas, L. W., Fagerness, V. L. (1984). Dynamics of microbial plankton communities: experiments in Kaneohe Bay, Hawaii. Mar. Ecol. Prog. Ser. 16: 127-133

Murphy, L. S., Haugan, E. M. (1985). The distribution and abundance of phototrophic ultraplankton in the North Atlantic. Limnol. Oceanogr. 30: 47-58

Nakamura, Y. (1990). Chemical environment for red tides due to Chattonella antiqua. Part 3 . Roles of iron and copper. J. oceanogr. Soc. Japan 46: 84-95

Nakamura, Y., Sawai, K., Watanabe, M. (1986). Growth inhibition of a red tide flagellate, Chattonella antiqua by copper. J. oceanogr. Soc. Japan 42: 481-486

Nakamura, Y., Takashima, J., Watanabe, M. (1988). Chemical environment for red tides due to Chattonella antiqua in the Seto Inland Sea, Japan. Part 1. Growth bioassay of the seawater and dependence of growth rate on nutrient concentrations. J. oceanogr. Soc. Japan 44: 113-124

Nakamura, Y., Umemori, T. (1991). Encystment of the red tide flagellate Chattonella antiqua (Raphidophyceae): cyst yield in batch cultures and cyst flux in the field. Mar. Ecol Prog. Ser 78: 273-284

Nakamura, Y., Umemori, T., Watanabe, M. (1989). Chemical environment for red tides due to Chattonella antiqua. Part 2. Daily monitoring of the marine environment throughout the outbreak period. J oceanogr. Soc. Japan 45: $116-128$

Nakamura, Y., Watanabe, M. M. (1983). Growth characteristics of Chattonella antiqua. Part 2. Effects of nutrients on growth. J. oceanogr. Soc. Japan 39: 151-155

This article was submitted to the editor
Pick, F. R. (1991). The abundance and composition of freshwater picocyanobacteria in relation to light penetration Limnol. Oceanogr. 36: 1457-1562

Pick, F. R., Bérubé, C. (1992). Diel cycles in the frequency of dividing cells of freshwater picocyanobacteria. J. Plankton Res. 14: 1193-1198

Porter, L. M., Fuhrman, J. A. (1990). Viral mortality of marine bacteria and cyanobacteria. Nature 343: 60-62

Ray, R. T., Haas, L. W., Sieracki, M. E. (1989). Autotrophic picoplankton dynamics in a Chesapeake Bay sub-estuary. Mar. Ecol. Prog. Ser. 52: 273-285

Sherr, E. B., Sherr, B. F., Berman, T., Hadas, O. (1991). High abundance of picoplankton-ingesting ciliates during late fall in Lake Kinnert, Israel. J. Plankton Res. 13: 789-799

Sieburth, J. McN., Smetacek, V., Lenz, J (1978). Pelagic ecosystem structure: heterotrophic compartments of the plankton and their relationship to plankton size fractions. Limnol. Oceanogr. 23: 1256-1263

Stockner, J. G. (1988). Phototrophic picoplankton: an overview from marine and freshwater ecosystems. Limnol. Oceanogr 33: $765-775$

Suttle, C. A., Chan, A. M., Cottrell, M. T. (1990). Infection of phytoplankton by viruses and reduction of primary productivity. Nature 347: 467-469

Takahashi, M., Kikuchi, K., Hara, Y. (1985). Importance of picocyanobacteria biomass (unicellular, blue-green algae) in the phytoplankton population of the coastal waters off Japan. Mar. Biol. 89: 63-69

Takeda, S., Kamatani, A. (1989). Photoreduction of Fe(III)EDTA complex and its availability to the coastal diatom Thalassiosira weissflogii. In: Okaichi, T., Anderson, D. M., Nemoto, T. (eds.) Red tides: biology, environmental science, and toxicology. Elsevier, New York, p. 349-352

Watanabe, M. M., Nakamura, Y., Mori, S., Yamochi, S. (1982) Effects of physico-chemical factors and nutrients on the growth of Heterosigma akashiwo Hada from Osaka Bay, Japan. Jap. J. Phycol. 30: 279-288

Waterbury, J. B., Watson, S. W., Guillard, R. R. L., Brand, L. E. (1979). Widespread occurrence of a unicellular, marine, planktonic cyanobacterium. Nature 277: 293-294

Waterbury, J. B., Watson, S. W., Valois, F. W., Franks, D. G. (1986). Biological and ecological characterization of the marine unicellular cyanobacteria Synechococcus. In: Platt, T., Li, W. K. W. (eds.) Photosynthetic picoplankton. Can. Bull. Fish. Aquat. Sci. 214: 71-120

Weisse, $T$ (1988). Dynamics of autotrophic picoplankton in Lake Constance. J. Plankton Res. 10: 1179-1188

Wells, M. L., Mayer, L. M., Guillard, R. R. L. (1991). A chemical method for estimating the availability of iron to phytoplankton in seawater. Mar. Chem. 33: 23-40

Manuscript first received: January 12, 1993

Revised version accepted: March 31, 1993 